\title{
Production of cast aluminium-graphite particle composites using a pellet method
}

\author{
B. C. PAI* \\ P. K. ROHATGI \\ Department of Mechanical Engineering, Indian Institute of Science, \\ Bangalore 560 012, India
}

Materials Science Division, National Aeronautical Laboratory Bangalore 560017, India

Copper-and nickel-coated graphite particles can be successfully introduced into aluminium-base alloy melts as pellets to produce cast aluminium-graphite particle composites. The pellets were made by pressing mixtures of nickel-or copper-coated graphite particles and aluminium powders together at pressures varying between 2 and $20 \mathrm{~kg} \mathrm{~mm}^{-2}$. These pellets were dispersed in aluminium alloy melts by plunging and holding them in the melts using a refractory coated mild steel cone, until the pellets disintegrated and the powders were dispersed. The optimum pressure for the preparation of pellets was 2 to $5 \mathrm{~kg} \mathrm{~mm}^{-2}$ and the optimum size and percentage of aluminium powder were 400 to $1000 \mu \mathrm{m}$ and $35 \mathrm{wt} \%$ respectively. Under optimum conditions the recovery of the graphite particles in the castings was as high as $96 \%$, these particles being pushed into the last freezing interdendritic regions. The tensile strength and the hardness of the graphite aluminium alloys made using the pellet method are comparable to those of similar composites made using gas injection or the vortex method. The pellet method however has the advantage of greater reproducibility and flexibility. Dispersion of graphite particles in the matrix of cast aluminium alloys using the pellet method increases their resistance to wear.

\section{Introduction}

Several processes involving introduction of particles [1] like graphite, alumina and silicon carbide in aluminium-base alloy melts to produce cast particulate composites have been recently developed [2-4]. The earlier attempts consisted of introduction of nickel-coated graphite, alumina and silicon carbide in aluminium and zinc based alloys by injecting these particles into the melt using a stream of nitrogen gas [4]. A later method involved stirring the alloy melts using an impeller, and then introducing nickel- or coppercoated graphite, or nickel-coated alumina particles at the centre of the vortex produced by stirring [2-5].

In this paper a new method of producing aluminium-graphite particle composite alloys is described in which the copper- or nickel-coated graphite particles are mixed with aluminium powder. These powder mixtures are pressed into pellets and plunged into aluminium alloy melts prior to the hand-stirring of the melt, followed by casting. The variables examined were the optimum size and amount of aluminium powder, the pressure applied to make the pellet, and the size of the coated graphite particles. The pellet technique of producing graphitic aluminium alloys is attractive since it is easier to reproduce and control the composition using this technique than using either the gas injection or the vortex technique.

\section{Materials used}

Pellets made from mixtures of aluminium powder and coated graphite powder were introduced into

\footnotetext{
* Formerly with Indian Institute of Science, Bangalore, India.
} 
several aluminium-base alloys to check the effect of the base alloy composition. The various alloys examined had the following compositions:

Pure aluminium $\mathrm{Al}-0.2 \% \mathrm{Si}-0.2 \% \mathrm{Fe}$

$\begin{array}{ll}\text { Alloy } 1 & \mathrm{Al}-4.2 \% \mathrm{Si}-3.2 \% \mathrm{Cu}-0.2 \mathrm{Mg} \\ & -0.6 \% \mathrm{Mn}\end{array}$

Alloy 2

$\mathrm{Al}-0.2 \% \mathrm{Si}-4.5 \% \mathrm{Cu}-0.2 \% \mathrm{Fe}$

Alloy 3

$\mathrm{Al}-7.2 \% \mathrm{Si}-0.2 \% \mathrm{Cu}-0.2 \% \mathrm{Fe}$

Alloy 4

$\mathrm{Al}-0.2 \% \mathrm{Si}-0.8 \% \mathrm{Cu}-0.2 \% \mathrm{Fe}$ $-10 \% \mathrm{Mg}$

\section{Experimental procedure}

2 to $4 \mathrm{~kg}$ heats of the above alloys were melted in an oil-fired or electrical-resistance furnace to a temperature $\sim 750$ to $850^{\circ} \mathrm{C}$. Cylindrical pellets of $2 \mathrm{~cm}$ diameter and $5 \mathrm{~cm}$ high were prepared by mixing the nickel- or copper-coated graphite powders with aluminium powders, and pressing the powder mixtures in hardened steel die. Coated graphite particles were used with aluminium powders of different sizes. The pellets were plunged into alloy melts (contained in $25 \mathrm{~cm}$ height $\times 15 \mathrm{~cm}$ diameter crucibles) using refractorycoated mild-steel cups which were withdrawn after a few sec. The melts were then stirred manually and cast into permanent moulds made out of cast steel. In some cases the melts were also cast in sand moulds. The linear and volume shrinkage of the alloys were measured using standard [6] procedure.

The distribution of graphite particles in the castings were studied macroscopically as well as microscopically. Chemical analysis was done to determine the graphite content in different parts of the various castings. The size of coated powders ranged from 20 to $200 \mu \mathrm{m}$. The size of the aluminium powder used as binder ranged from 40 to $1000 \mu \mathrm{m}$. The compacting pressures experimented with ranged from 1 to $25 \mathrm{~kg} \mathrm{~mm}^{-2}$.

\section{Results and discussion}

\subsection{Effect of compacting pressures}

Pellets were prepared by compacting homogeneous mixtures of aluminium powder and coated graphite particles. At pressures below $2 \mathrm{~kg} \mathrm{~mm}^{-2}$ the compacts had poor strength, and so higher pressures were used. However, the compacts prepared at pressures above $10 \mathrm{~kg} \mathrm{~mm}^{-2}$ were too hard to disintegrate when they were added to the melt, and they tried to float out of the melts shortly after their addition. Above a pressure of $20 \mathrm{~kg}$
TABLE I Effect of compacting pressure on the percentage recovery of graphite particles in the castings (aluminium particle size 400 to $1000 \mu \mathrm{m}$ with $35 \mathrm{wt} \%$ aluminium powder in the compact). Thickness of copper and nickel coating over graphite particle is approximately 2 to $5 \mu \mathrm{m}$.

\begin{tabular}{lll}
\hline $\begin{array}{l}\text { Compacting } \\
\text { pressure } \\
\left(\mathrm{kg} \mathrm{mm}^{-2}\right)\end{array}$ & $\begin{array}{l}\text { Coating on } \\
\text { the } 80 \mu \mathrm{m} \\
\text { size graphite } \\
\text { particle }\end{array}$ & $\begin{array}{l}\text { Percentage } \\
\text { recovery of } \\
\text { graphite in the } \\
\text { castings }\end{array}$ \\
\hline Less than 1 & Copper & $\begin{array}{l}\text { Not possible to get } \\
\text { a compact }\end{array}$ \\
1.5 & copper & 60 \\
& nickel & 50 \\
2.8 & copper & 96 \\
& nickel & 96 \\
4.2 & copper & 90 \\
& nickel & 92 \\
5.2 & copper & 80 \\
& nickel & 85 \\
6.8 & copper & 40 \\
& nickel & 45 \\
8.0 & copper & 20 \\
12.0 & nickel & 40 \\
& copper & 20 \\
15.0 & nickel & 35 \\
& nickel & Not possible to \\
& & disperse \\
\hline
\end{tabular}

$\mathrm{mm}^{-2}$ the metal coatings on the graphite started to peel off as a result of pressing. The best results were obtained in the range 3 to $5 \mathrm{~kg} \mathrm{~mm}^{-2}$, depend. ing upon the ratio of the aluminium powder to the coated particles, and the nature of the coating (Table I).

\subsection{Effect of aluminium powder particle size}

Aluminium powder particles were used as both a binder and a dispersing medium for metal-coated graphite particles. (Aluminium powder particles of 400 to $1000 \mu \mathrm{m}$ in size gave the best results). Particles larger than $1000 \mu \mathrm{m}$ required higher pressures for compaction into pellets with suitable green strength, in addition the powder mixture is inhomogeneous due to large differences in the size of the aluminium-coated graphite powder. When the particle size of the aluminium powder was below $400 \mu \mathrm{m}$, undesirably higher pressures were required to get compacts with suitable green strength. The best results were obtained when the particle size of aluminium powder ranged from 400 to $1000 \mu \mathrm{m}$. It was found that a mixture of aluminium powder of wide range of sizes gave better results than a powder with a narrow range (Table II). 
TABLE II Effect of particle size of aluminium powder (used as a binder) on the recovery of graphite particles (Aluminium powder used $35 \%$ by weight of the compact).

\begin{tabular}{llll}
\hline $\begin{array}{l}\text { Average particle } \\
\text { size of alumin- } \\
\text { ium powder } \\
(\mu \mathrm{m})\end{array}$ & $\begin{array}{l}\text { Coating on } \\
\text { graphite } \\
\text { particles }\end{array}$ & $\begin{array}{l}\text { Compacting } \\
\text { pressures } \\
\text { used } \\
\left(\mathrm{kg} \mathrm{mm}^{-2}\right)\end{array}$ & $\begin{array}{l}\text { Percentage } \\
\text { graphite } \\
\text { recovered in } \\
\text { the castings }\end{array}$ \\
\hline 1000 & copper & 5.0 & 50 \\
$400-1000$ & copper & 2.8 & 96 \\
& nickel & 2.8 & 95 \\
$20-400$ & copper & 2.8 & 90 \\
& nickel & 2.8 & 92 \\
$200-400$ & copper & 3.4 & 80 \\
& nickel & 3.4 & 85 \\
$45-200$ & copper & 2.8 & 70 \\
& nickel & 2.8 & 78 \\
45 & copper & 2.8 & Not \\
& & & possible to \\
& & 5.2 & 25 \\
\hline
\end{tabular}

TABLE III Effect of amount of aluminium (used as a binder) used on recovery of the graphite particles.

\begin{tabular}{llll}
\hline $\begin{array}{l}\text { w\% aluminium } \\
\text { powder in the } \\
\text { pallet }\end{array}$ & $\begin{array}{l}\text { Particle } \\
\text { size of } \\
\text { aluminium } \\
\text { powder } \\
(\mu \mathrm{m})\end{array}$ & $\begin{array}{l}\text { Compacting } \\
\text { pressure } \\
\left(\mathrm{kg} \mathrm{mm}^{-2}\right)\end{array}$ & $\begin{array}{l}\text { Percentage } \\
\text { graphite } \\
\text { recovered } \\
\text { in the } \\
\text { castings }\end{array}$ \\
\hline 10 & $400-1000$ & 2.8 & $\begin{array}{l}\text { Not } \\
\text { possible } \\
\text { to get }\end{array}$ \\
& & & good \\
& & & 80 \\
& & & 80 \\
20 & $200-400$ & 3.4 & 80 \\
30 & $400-1000$ & 2.8 & 96 \\
35 & $200-400$ & 2.8 & 90 \\
50 & $400-1000$ & 2.8 & 96 \\
& $200-400$ & 2.8 & 60 \\
& $400-1000$ & 2.8 & 90 \\
& $<45$ & 3.2 & 96 \\
\hline
\end{tabular}

\subsection{Optimum percentage of aluminium powder in the pellets}

It was found that aluminium particles act as binders during compaction of the mixtures of aluminium and metal-coated graphite particles, because they show greater plasticity than the metal-coated graphite particles. The aluminium present in the pellets also acts as a dispersing agent. When the pellet is added to the melts, the aluminium expands more than the nickel, copper or graphite powder, and pushes the particles out (coefficient of linear expansion of $\mathrm{Al}=23 \times 10^{-6}$ $\mathrm{cm} \mathrm{cm}{ }^{-10} \mathrm{C}^{-1}, \mathrm{Cu} 16.7 \times 10^{-6} \mathrm{~cm} \mathrm{~cm}^{-10} \mathrm{C}^{-1}$, Ni $13.3 \times 10^{-6} \mathrm{~cm} \mathrm{~cm}^{-10} \mathrm{C}^{-1}$, graphite $7.9 \times 10^{-6}$ $\mathrm{cm} \mathrm{cm}^{-10} \mathrm{C}^{-1}$ ). Furthermore, when the aluminium in the pellet melts it is accompanied by an expansion in volume pushing the graphite particles farther apart. Liquid aluminium easily flows between the metal-coated graphite particles, due to its wettability with copper or nickel, (and its ability to dissolve copper or nickel) and disperses the metal-coated graphite particles in the liquid aluminium bath. If the amount of aluminium added is on the lower side, then the metal coating on the graphite either gets oxidized or metalcoated particles get sintered to each other resulting in poor yields and dispersion. The optimum ratio of aluminium powder to the coated graphite powder was found to be about $1: 2$ by weight (Table III).

\subsection{The green density of the compact}

The optimum green density of the compact for successful dispersion was $\sim 2.4$ to $2.6 \mathrm{~g} \mathrm{~cm}^{-3}$. The pellets therefore had a tendency to float when they were introduced into the molten aluminium alloys. Hence it was necessary to hold the pellet in the molten metal for a few seconds using a refractory-coated inverted mild steel cup. The denser the compact, the more time it takes to disintegrate and there is a greater probability of it floating out before it disintegrates. It was found that if by any chance the pellet floats to the surface of the melt even for a short period, the copper or nickel coating would get oxidized leading to the rejection of the graphite particles from the melt.

\subsection{Effect of the melt composition}

A change in the melt composition changes the fluidity and the reactivity of the melts. Alloying elements like silicon and magnesium were found

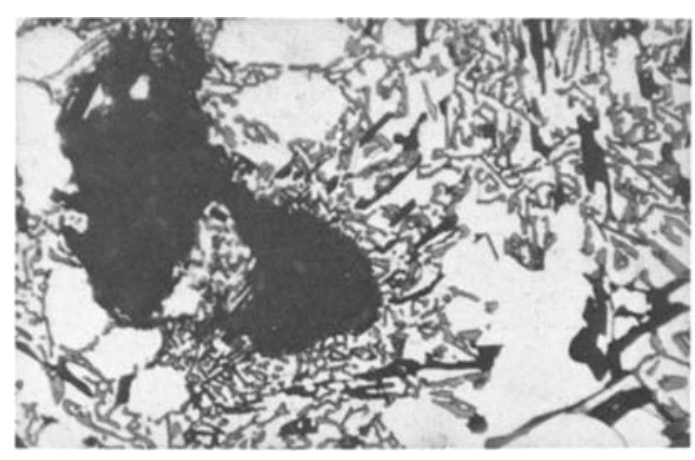

Figure 1 Graphite particles surrounded by $\mathrm{Si}$ and $\mathrm{CuAl}_{2}$ phases in the interdendritic regions. Matrix alloy: $\mathrm{Al}$ $4.2 \% \mathrm{Si}-3.2 \mathrm{Cu}$ with $2 \%$ graphite. $(620 \mathrm{X})$. 
to alter the recoveries of graphite in the castings significantly. It was also observed that with an increase in the silicon content, the recoveries of graphite increased significantly. Probably silicon forms either a metastable phase with graphite or is adsorbed on the surface of the graphite particles reducing their flotation rate in the melts (Fig. 1). In addition the presence of silicon increases the fluidity of the aluminium melt so that it can flow more readily between the particles. The presence of magnesium in the alloy also increases the recovery of graphite particles, other conditions being the same. However, despite these slight variations in the efficiencies of graphite recoveries with different alloys, in general it was possible to disperse graphite in the matrix of all the alloys listed earlier with sufficiently high recoveries.

\subsection{Casting characteristics of the graphitic aluminium:}

The graphitic aluminium alloys (made by the pellet technique described in this paper) showed lower linear and volume shrinkage compared to the alloys of same composition (including copper) but without graphite. The linear shrinkage was measured by casting a bar of $2.5 \mathrm{~cm}$ square section and $30 \mathrm{~cm}$ length in a sand mould by chill cast bar technique [6]. The volume shrinkage was measured by casting a hemisphere of $10 \mathrm{~cm}$ diameter in a sand mould. Both the linear shrinkage and volume shrinkage of graphitic aluminium alloys were of the order of $4 \%$, the shrinkage of the alloys without graphite was of the order of $5 \%$. The fluidity of the graphitic aluminium alloy melt is less than that of pure aluminium or aluminiumbase alloys. Similar observations have been made earlier [7]. Centre line piping is less in graphitic

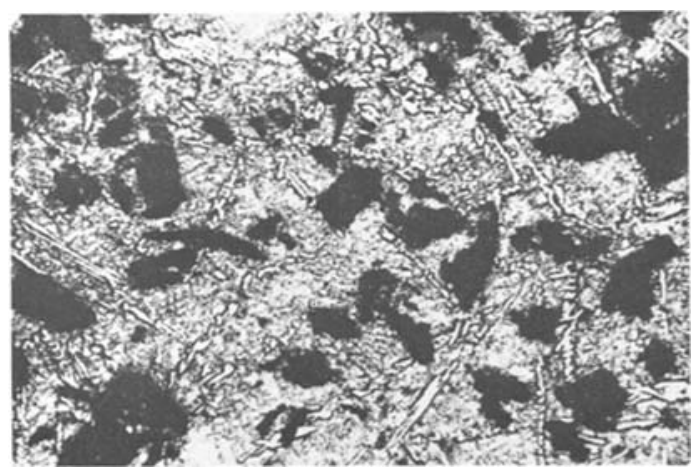

Figure 2 Distribution of graphite in longitudinal section of rod casting of $\mathrm{Al}-7.2 \% \mathrm{Si}-6.7 \% \mathrm{Ni}-6.6 \%$ graphite alloy. (124 X). aluminium alloys as compared to alloys with same chemical composition but without graphite. Similar observations were made during the solidification of aluminium alloys containing dispersed alumina particles [8]. Apparently the presence of suspended particles distributes the shrinkage microporosity across the entire cross-section of the castings: such distributed microporosity would be an advantage in bearing applications where it would retain some oil, even though it would detract from the mechanical properties.

\subsection{Macroscopic and microscopic distri- bution of graphite particles}

Figs. 2 and 3 show that the microscopic distribution of the graphite alloy in both the longitudinal and transverse sections of the $5 \mathrm{~cm}$ diameter bar were quite uniform and similar. The distance between neighbouring graphite particles ranges on an average between 100 and $1000 \mu \mathrm{m}$. Occasionally there are clusters where the graphite particles are in contact with each other (Fig. 4), perhaps due to the incomplete disintegration of the pellets. There are regions which are relatively free from graphite (Fig. 5) where the interparticle distances are as large as $10000 \mu \mathrm{m}$. Since these alloys have mainly antifriction applications, these levels of inhomogenity in the microscopic distribution are adequate to provide antifriction properties. Previous work has shown $[9,10]$ that aluminium with a similar graphitic distribution has antiseizing properties and excellent wear resistance under boundary lubrication conditions. Metallographic examinations show that graphite particles are generally present at the interdendeitic regions, instead of being present within the dendrites (Figs. 5 and 6). Apparently the graphite particles are pushed by the advancing solidification from in to the last-freezing interdendritic liquid.

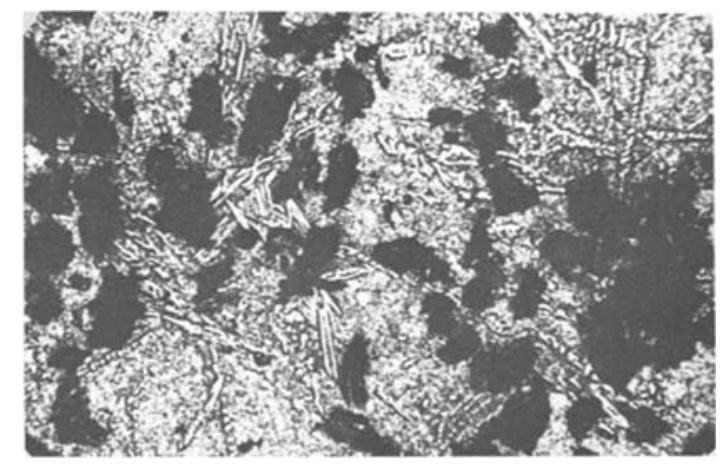

Figure 3 Distribution of the graphite in transverse section of the same alloy casting as Fig. 2. (124X). 

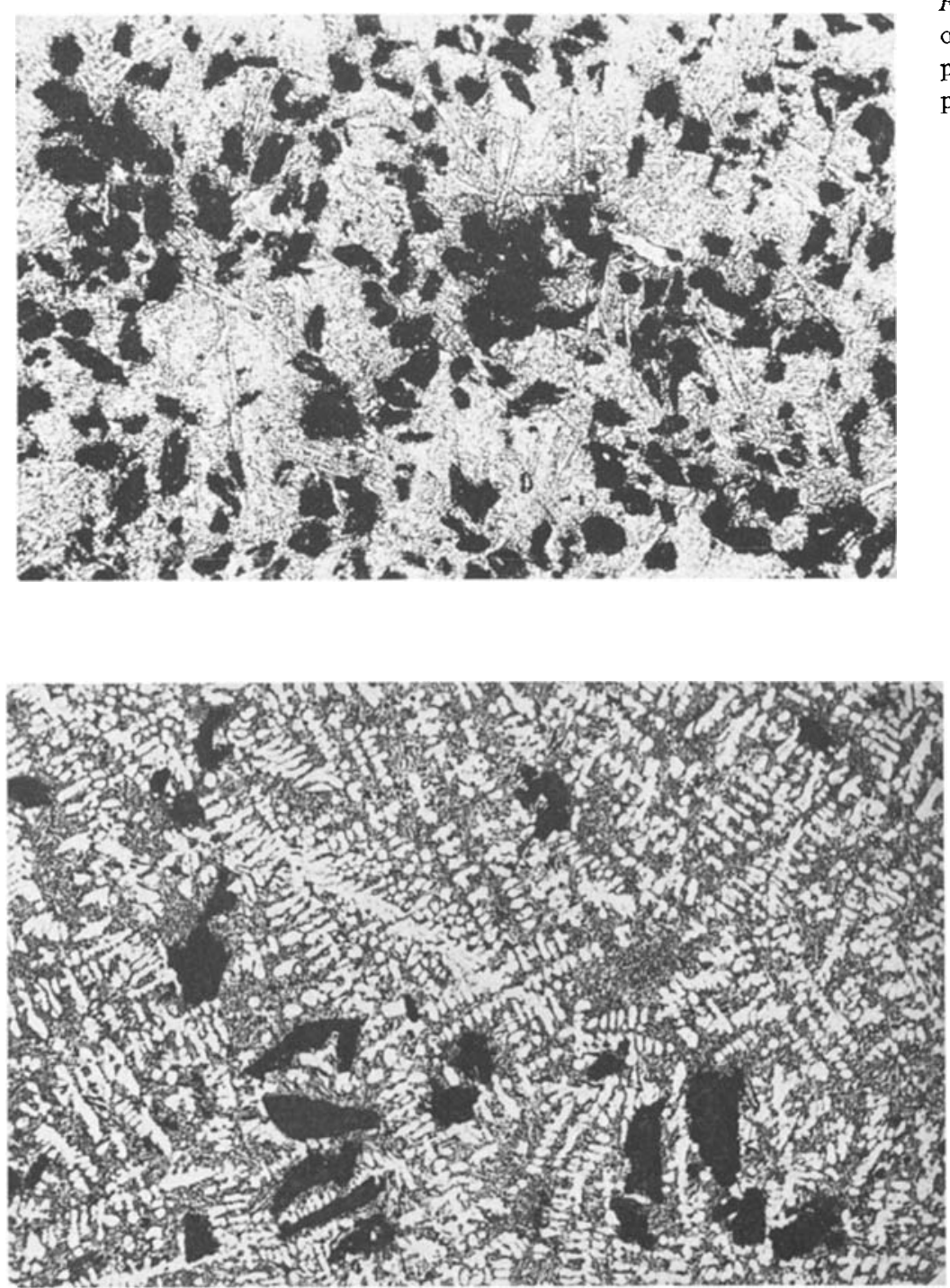

Figure 4 Tendency for clustering of graphite particles when the pellets do not disintegrate properly. $(90 \mathrm{X})$.
Figure 5 Graphite particles are distributed in the interdendritic regions. Matrix alloy Al-7.2\% $\mathrm{Si}-2.2 \% \mathrm{Cu}$ with $2 \%$ graphite. $(90 \mathrm{X})$.

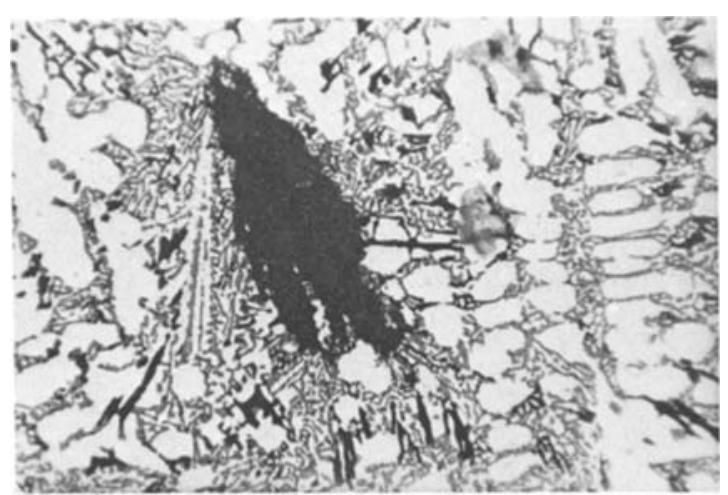

Figure 6 Graphite particle trapped in the last freezing liquid. (496 X).

\subsection{Mechanical properties of the alloys}

The tensile properties and hardness of the alloys are listed in Table IV. Generally additions of copper-coated graphite result in a slight decrease in the hardness of these alloys. Since additions of copper alone would lead to an increase in the hardness, these results indicate that addition of graphite results in a decrease in the hardness of these alloys. Solutionizing and ageing treatment of $\mathrm{Al}-4.5 \% \mathrm{Cu}-2.2 \%$ graphite alloy resulted in an increase in the hardness from $25 \mathrm{Rb}$ in the case state to $30 \mathrm{Rb}$ after solution treatment and to $38 \mathrm{Rb}$ after ageing. These results show that graphitebearing copper-containing aluminium alloys res- 
TABLE IV Mechanical properties of graphitic aluminium alloys in as-cast condition.

\begin{tabular}{llll}
\hline $\begin{array}{l}\text { Alloy composition } \\
\text { in wt } \%\end{array}$ & $\begin{array}{l}\text { Ultimate } \\
\text { tensile } \\
\text { strength } \\
\left(\mathrm{kg} \mathrm{mm}^{-2}\right)\end{array}$ & $\begin{array}{l}\text { Percentage } \\
\text { elongation } \\
\left(\mathrm{m} \mathrm{m}^{-1}\right)\end{array}$ & $\begin{array}{l}\text { Hardness } \\
(\mathrm{Rb})\end{array}$ \\
\hline $\mathrm{Al}-0.2 \mathrm{Si}-0.2 \mathrm{Fe}$ & 10.2 & 1.8 & 17 \\
$\mathrm{Al}-1.8 \mathrm{Cu}-1.6 \mathrm{Gr}$ & 8.3 & 1.2 & 16 \\
$\mathrm{Al}-2.8 \mathrm{Cu}-2.2 \mathrm{Gr}$ & 7.6 & 0.9 & 16 \\
$\mathrm{Al}-4.2 \mathrm{Si}-3.2 \mathrm{Cu}$ & 16.7 & 1.0 & 28 \\
$-0.6 \mathrm{Mn}$ & & & \\
$\mathrm{A} 1-4.2 \mathrm{Si}-4.3 \mathrm{Cu}$ & 14.5 & 0.8 & 32 \\
$-0.6 \mathrm{Mn}-1.5 \mathrm{Gr}$ & & & 33 \\
$\mathrm{Al}-4.2 \mathrm{Si}-3.2 \mathrm{Cu}$ & 13.5 & 1.0 & \\
$-2.4 \mathrm{Gr}-2.5 \mathrm{Ni}$ & & & 26 \\
$\mathrm{Al}-4.2 \mathrm{Cu}$ & 14.3 & 1.1 & 18 \\
$\mathrm{Al}-4.2 \mathrm{Cu}-1.9 \mathrm{Ni}$ & 12.1 & 0.8 & 17 \\
$-1.8 \mathrm{Gr}$ & & & \\
$\mathrm{Al}-4.2 \mathrm{Cu}-2.4 \mathrm{Ni}$ & 10.7 & 0.6 & 29 \\
$-2.2 \mathrm{Gr}$ & & & 27 \\
$\mathrm{Al}-7.2 \mathrm{Si}$ & 15.1 & 1.1 & \\
$\mathrm{Al}-7.2 \mathrm{Si}-1.8 \mathrm{Cu}$ & 14.7 & 0.9 & 37 \\
$-1.9 \mathrm{Gr}$ & & & \\
$\mathrm{Al}-7.2 \mathrm{Si}-3.0 \mathrm{Ni}$ & 12.3 & 0.9 & \\
$-2.8 \mathrm{Gr}$ & & & \\
$\mathrm{Al} 1-10 \mathrm{Mg}$ & 16.6 & 1.3 & 30 \\
$\mathrm{Al}-10 \mathrm{Mg}-3.1 \mathrm{Cu}$ & 12.5 & 0.78 & \\
$-2.8 \mathrm{Gr}$ & & & \\
\hline
\end{tabular}

${ }^{*}$ Gr denotes graphite.

pond to solutionizing and ageing treatment. This will permit the production of alloys with a range of strengths and ductilities to suit the desired applications.

Limited tensile property measurements show that additions of copper-coated graphite particles decrease the tensile strength and ductility of aluminium-base alloys. Apparently the presence of graphite decreases the strength since additions of copper alone would lead to an increase in the tensile strength. However, for several antifriction applications the properties of the graphitic aluminium alloys made by the pellet technique are adequate [9] .

\subsection{Advantages of the pellet technique:}

Both in the gas injection method [4] and in the vortex method of dispersing graphite particles in aluminium alloy melts $[2,3]$, there is a problem of transferring the particle from the air or the gas bubble into the bath of molten metal. However in the pellet method this problem is overcome since the pellet is already under the surface of the molten metal, held by the metal cup. The expanding gases entrapped between the powder particles, and expansion of aluminium powder particles while they are heated to the bath temperature (and then subsequently while melting), helps to disintegrate the pellet and disperse the powder into the melts. In fact it was shown that particles finer than about $40 \mu \mathrm{m}$ can only be introduced in the melts using pellets similar to ours; the use of other methods to introduce these fine particles in the melt leads to the rejection of these particles [11].

The pellet method is also likely to be more reproducible and readily adaptable by the foundries than the Vortex method. In the gas injection and vortex method the skill of the operator is important in getting reproducible results. In the case of the pellet technique, the pellets have only to be plunged into the melt and stirred. The pellets can be made by one organization and transported much more easily than the stirrer assembly, to make graphitic aluminium alloys in different foundries.

One of the potential disadvantages of the pellet technique is that the pellet contains a layer of oxide on aluminium powder which gets dispersed in the melt. However the calculations show that for $1.5 \mu \mathrm{m}$ thick oxide coating generally found on $1000 \mu \mathrm{m}$ powder, the amount of oxides introduced in the melt will be of the order of $0.5 \%$ of the weight of the casting for $2 \%$ addition of the powder. Some of this aluminium oxide layer introduced in the melt may even be removed from the melt, and therefore this value represents the upper limit of aluminium oxide introduced in the melt. Chemical analysis showed that the alumina content in a typical graphite-aluminium castings made by the pellet technique was less than $0.1 \mathrm{wt} \%$. Likewise microscopic examination at high magnifica-

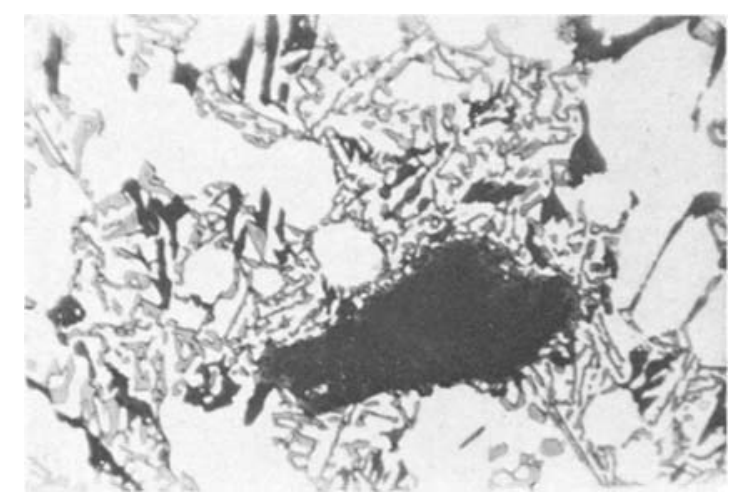

Figure 7 Graphite particles surrounded by $\mathrm{Si}$ and $\mathrm{CuAl}_{2}$ phase matrix do not contain any alumina particles. $(620 \mathrm{X})$. 
tion does not reveal any significant volume percentage of aluminium oxide in the castings (Fig. 7).

The wear resistance of cast aluminium-graphite particle composites made using the pellet method were measured against a rotating steel disc [9]. It was found that incorporation of graphite particles increased the wear resistance of the base aluminium alloys. When the graphite content was more than $2.2 \%$ the composite aluminium alloys were able to run against the steel disc without seizing even when the oil supply was discontinued. Other seizure tests that were run indicate that aluminium graphite particle alloys can be used in antifriction applications.

\section{Conclusions}

(1) Graphite particles can be dispersed in the matrix of cast aluminium-base alloys by plunging pellets, made from a mixture of aluminium powder and copper- or nickel-coated graphite powder in the melts prior to casting.

(2) For the most efficient recovery of graphite particles in the castings, the pellets should be made from a mixture of $67 \mathrm{wt} \%$ of $80 \mu \mathrm{m}$ copper- or nickel-coated powder and $33 \mathrm{wt} \%$ of $400 \mu \mathrm{m}$ size aluminium powder, and the pellet should be compressed at pressures of 2 to $5 \mathrm{~kg} \mathrm{~mm}^{-2}$.

(3) The macroscopic distribution of the graphite particles is uniform in permanent mould castings. On a microscopic scale the graphite particles are generally present in the interdendritic regions, and the distance between the neighbouring graphite particles varies from 100 to $1000 \mu \mathrm{m}$.

(4) Addition of copper-coated graphite particles generally leads to a slight decrease in the tensile strength, ductility and hardness of the base aluminium alloys. The graphite dispersed aluminium alloys respond to solution and ageing treatment.

\section{References}

1. D. N. WILLIAMS, J. W. ROBERTS and R. I. JAFFE, Modern Castings 37 (1960) 81.

2. F. A. BADIA, D. E. MCDONALD and J, R. PEARSON, AFS Trans 79 (1971) 265.

3. F. A. BADIA, ibid 79 (1971) 369.

4. F. A. BADIA and P. K. ROHATGI, ibid 77 (1969) 402.

5. B. C. PAI and P. K. ROHATGI, Mater. Sci. Eng. 21 (1975) 161.

6. J. LAING and R. T. ROLFE, "A Manual of Foundry Practice" (Chapman and Hall, London, 1938).

7. M. K. SURAPPA, M.S. Thesis, Department of Mechanical Engineering, Indian Institute of Science, Bangalore, 1975.

8. B. C. PAI, P. K. ROHATGI, K. V. PRABHAKER and SUBRAT RAY, Mater. Sci. Eng. 24 (1976) 31.

9. B. C. PAI, P. K. ROHATGI and S. VENKATESH, Wear 30 (1974) 117 .

10. F. A. BADIA and P. K. ROHATGI, SAE Trans. 78 (1969) 1200.

11. YU. Z. BABASKIN, V. A. EFINOV, A. A. MULIK, E. D. TARANOV and G. G. LUTSENKO, Russian Casting Production, August (1972) 328.

Received 15 April and accepted 17 May 1977. 